\title{
Bacterial production in the Rhône River plume: effect of mixing on relationships among microbial assemblages
}

\author{
David Kirchman ${ }^{1}$, Yenise Soto ${ }^{2}$, France Van Wambeck ${ }^{2}$, Micheline Bianchi $^{2}$ \\ ${ }^{1}$ College of Marine Studies, University of Delaware, Lewes, Delaware 19958, USA \\ ${ }^{2}$ CNRS Campus de Luminy, Case 907, Route Leo Lachamp, F-13288 Marseille Cedex 9, France
}

\begin{abstract}
We examined inorganic nutrients and microbial assemblages in the Rhone River plume during January 1987. When wind speed is low the plume forms a transient layer of high nutrient-low salinity water overlaying the Mediterranean Sea which has very low nutrient concentrations. The vertical thickness of the plume was on the order of $100 \mathrm{~cm}$, and during one horizontal transect surface density decreased 2 -fold within $1 \mathrm{~km}$. Ammonium, nitrate, and phosphate concentrations were at least 10 -fold higher in the thin plume compared with Sea values. Bacterial production (thymidine and leucine incorporation) was higher by about 2-fold at plume-sea boundaries. Although bacterial biomass and production peaked with chlorophyll at plume-sea boundaries, the correlation between these bacterial parameters and chlorophyll concentrations was low. The ratio of bacterial biomass to phytoplankton biomass was greater than 1 for low salinity waters. Our results suggest that microbial loop relationships had been disrupted in the Rhone River plume because of the input of allochthonous carbon and because of rapid changes in growth conditions caused by mixing. In addition to affecting physico-chemical parameters, mixing appears to have diluted heterotrophic flagellate abundance which allowed increases in autotroph abundance and bacterial production.
\end{abstract}

\section{INTRODUCTION}

Because heterotrophic bacteria consume a large fraction of primary production (on the order of $50 \%$ ) in both marine and freshwater pelagic ecosystems (reviewed by Ducklow 1983, Cole et al. 1988), understanding the variation and controls of bacterial production is essential for examining the fate of primary production and the structure of pelagic ecosystems. When averaged over different seasons and regions, a large fraction (about $60 \%$ ) of the variation in bacterial production is explained by variation in rates of primary production (Cole et al. 1988). This observation implies that bacterial production is controlled by the organic matter produced by phytoplankton (Hobbie \& Cole 1984, Cole et al. 1988). Furthermore, in their review of several studies of both marine and freshwater systems, Cole et al. (1988) found no evidence that the ratio of bacterial production to primary production changes as primary production varies from system to system, suggesting that bacterial production is not limited by another factor even when primary production is high.
Clearly, primary production is important in determining the rate of bacterial production, but other factors apparently complicate this relationship. A log-log plot of bacterial production vs primary production leaves unexplained about $40 \%$ of the variation in bacterial production (Cole et al. 1988). Also, Cole et al. (1988) focussed on studies that reported estimates extended for some period of time so that seasonal, regional or annual values could be readily obtained.' On smaller time and space scales, the ratio of bacterial production to primary production or chlorophyll can vary greatly. Studies of river plumes offer some good examples. Albright (1983) found that primary production was low in the Fraser River (B.C., Canada), increased in the river plume, and reached maximum values in the Strait of Georgia. In contrast, bacterial production (estimated from thymidine incorporation) was highest in the river plume at a salinity between river and strait values. Similarly, Ducklow \& Kirchman (1983) found that bacterial production did not correlate with primary production during their study of the Hudson River (N.Y., USA) plume in spring. 
Because the ratio of bacterial production to primary production appears to be relatively constant for a great variety of pelagic systems (Cole et al. 1988), it is interesting and perhaps important to find systems where the ratio deviates from the expected, indicating that typical microbial loop relationships may be disrupted. The studies of Albright (1983) and Ducklow \& Kirchman (1983) suggest that the 'average' or 'normal' relationships between bacteria and phytoplankton (Cole et al. 1988) do not hold in river plumes. To investigate this possibility more thoroughly, we examined the plume of the Rhône River as it mixes with the Mediterranean Sea. When wind velocity is low, the Rhone River plume forms a thin lens of low salinity water with high nutrient concentrations which overlays high salinity water with low nutrient concentrations. We found that bacterial production was enhanced at plume-sea boundaries, which was only partly explained by elevated phytoplankton biomass at these boundaries. Our results suggest that factors other than rates of primary production, such as decreased grazing pressure on bacteria, are probably important in determining the spatial variation in bacterial production in the Rhone River plume.

\section{MATERIALS AND METHODS}

Three horizontal transects and 3 depth profiles were taken to map out the Rhône River plume. The eastern, western, and southern transects were on January 27 , 28, and 29, 1987, respectively (Fig. 1). Water samples were pumped up to the ship with a peristaltic pump through a $0.5 \mathrm{~cm}$ (inner diameter) Tygon tube at a rate of $1.31 \mathrm{~min}^{-1}$. Surface samples were roughly $10 \mathrm{~cm}$ deep while samples for depth profiles were taken at the depth indicated. Temperature and salinity were measured by a YSI meter (Yellow Springs Instrument Co.).

Ammonium concentrations were measured immediately on board (Strickland \& Parsons 1972) while samples for other inorganic nutrients were frozen first. After thawing, concentrations of nitrate, nitrite, silicate and phosphate were measured with an automatic Technicon analyzer. Chlorophyll concentrations were measured in acetone extracts by fluorometry (Strickland \& Parsons 1972, Neveux 1976). Numbers of heterotrophic bacteria and microflagellates were determined by epifluorescence microscopy using DAPI (diamidinophenylindole) (Porter \& Feig 1980) and image analysis (van Wambeke 1988). Microflagellates were counted using the double-staining technique (DAPI and FITC - fluorescein isothiocyanate) of Sherr \& Sherr (1983). Autotrophic microflagellates were distinguished from heterotrophic microflagellates by the presence of autofluorescing chlorophyll.

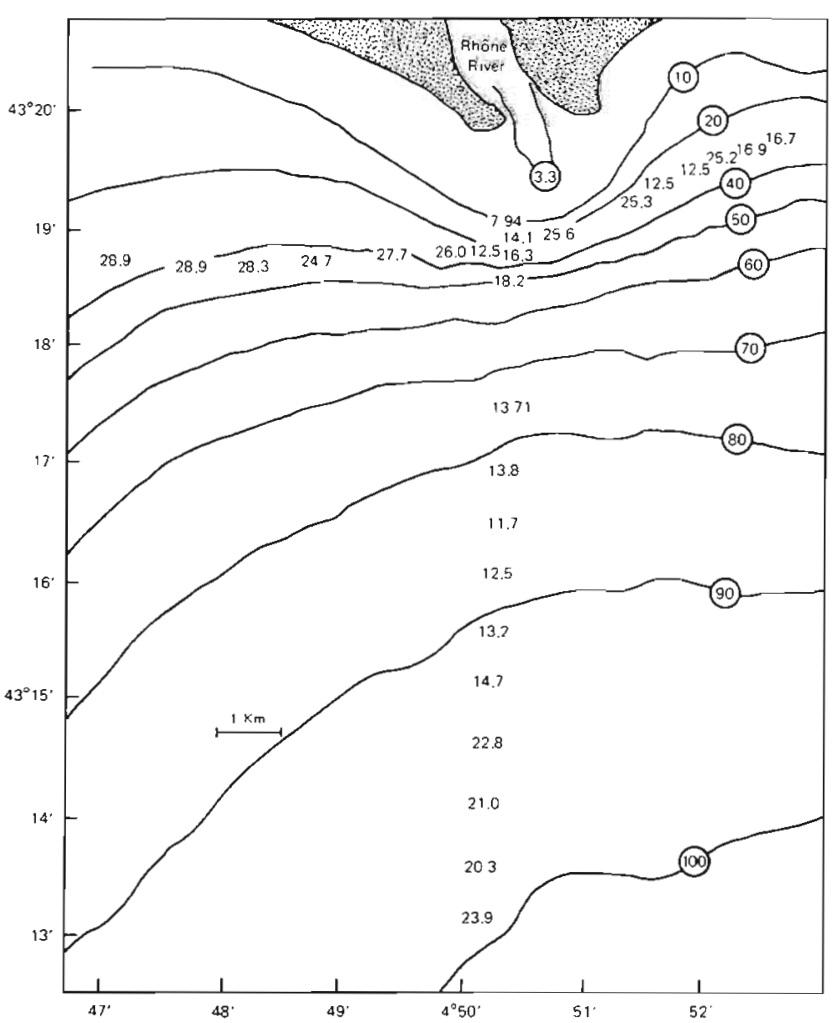

Fig. 1 Density distribution $\left(\sigma_{t}\right)$ during 3 transects (east, west and south) of Rhône River plume on Jan 27, 28 and 29, 1987 , respectively. Circled numerals are depths (m). Data for Figs. 2 and 4 were taken at the station with a density of 14.1, near the mouth of the Rhone. Data for Fig. 4 were collected along a westerly transect (the left-arm of the ' $T$ ') with densities ranging from 28.9 to 12.5

Incorporation rates of $\left[{ }^{3} \mathrm{H}\right]$ thymidine (Fuhrman \& Azam 1980) and $\left[{ }^{14} \mathrm{C}\right.$ leucine (Kirchman et al. 1985) were measured to estimate bacterial production. Briefly, $5 \mathrm{nM}$ (final concentration) of $\left[{ }^{3} \mathrm{H}\right]$ thymidine was added to $10 \mathrm{ml}$ subsamples. After $1 \mathrm{~h}$ incubation the samples were placed on ice and $1.1 \mathrm{ml}$ of $50 \%$ trichloroacetic acid (TCA) was added. The samples were kept on ice until filtration on shore (about $4 \mathrm{~h}$ ) through $0.45 \mu \mathrm{m}$ nitrocellulose filters (Sartorius). Samples for leucine incorporation were treated similarly, except that a hot TCA extraction was used (Kirchman et al. 1985). Incorporation rates were determined from triplicates and one TCA-killed control. In order to estimate rates of bacterial production, incorporation rates were multiplied by $2 \times 10^{18} \mathrm{cell} \mathrm{mol}^{-1}$ and $1 \times 10^{17}$ cell $\mathrm{mol}^{-1}$ for thymidine and leucine, respectively (Fuhrman \& Azam 1982, Kirchman \& Hoch 1988).

Although 3 horizontal transects and depth profiles were sampled, we will focus on one horizontal transect (west-to-east) and one depth profile (at the mouth). The other horizontal transects are less interesting because the boundary between plume and sea was not as dis- 
tinct. We do not have as much information on the biological parameters for the other 2 depth profiles discussed in detail. However all property vs salinity comparisons used data from all transects and depth profiles.

\section{RESULTS}

\section{Density structure}

As a first approximation, the predominate factor affecting the horizontal and vertical density field is the dilution of low salinity water from the Rhône River by high salinity water of the Mediterranean Sea ( $38 \%$ ). Our limited sampling enables only a sketchy and somewhat complicated description of plume hydrodynamics. Density did not change smoothly during the first transect, which was eastward from the mouth of the Rhône (Fig. 1). Patches of high salinity water were interdispersed among patches of low salinity water, which has been observed before (Blanc et al. 1969, Aloisi et al. 1979). These patches were visible from the ship, evident from variation in sea texture. The irregular changes in density were probably due to mixing caused by the westerly Liguro Provençal Current. Density increased regularly during the second, southern transect. Even at our southernmost station, surface salinities and temperatures never reached values typical of the Mediterranean. The east to west horizontal transect was the most interesting of the three. Density was relatively high for $6 \mathrm{~km}$ of the transect, then within $1 \mathrm{~km}$ decreased by 2 -fold near the mouth of the Rhone.

Variation in the density field was mostly due to salinity. Temperatures were somewhat higher in the Mediterranean Sea $\left(12^{\circ} \mathrm{C}\right)$ than in the Rhône River $\left(8^{\circ} \mathrm{C}\right)$.

Four depth profiles over $3 \mathrm{~d}$ were taken at a station close to the mouth of the Rhône, at the intersection of the 3 horizontal transects (Fig. 1). In all 4 profiles, there was a thin layer of low salinity water (on the order of $100 \mathrm{~cm}$ ) that overlaid the high salinity water of the Mediterranean Sea (Fig. 2). The thickness and salinity of the top layer varied greatly, even between 2 profiles taken on the same day (Fig. 2) due in part to internal waves. The depth of the top layer varied from 100 to $150 \mathrm{~cm}$ while salinity varied from 10 to $21 \%$.

\section{Distribution of inorganic nutrients}

Ammonium, nitrate and phosphate concentrations were highest in the low salinity waters of the plume and decreased as salinity increased. The high values

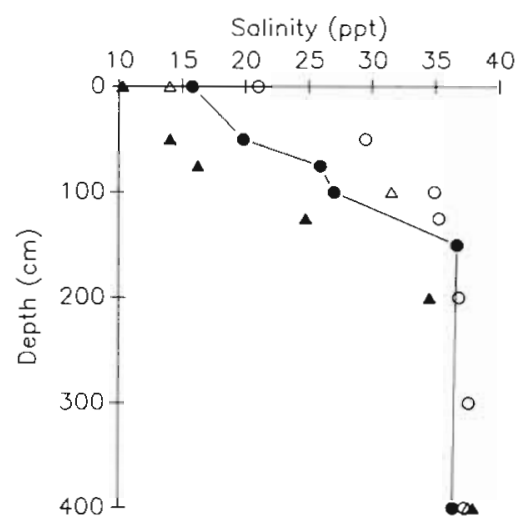

Fig. 2. Depth profiles of salinity in the Rhône River plume on Jan 27 (; 5 h later -), $28(\boldsymbol{\Lambda})$ and $29(\bullet), 1987$. Profiles were taken at the intersection fo the 3 transects shown on Fig. 1 , corresponding to a surface $\sigma_{1}$ of 14.1

Table 1 Summary of correlation coefficients for various parameters versus salinity in the Rhone River plume, January 1987

\begin{tabular}{|c|c|c|c|c|}
\hline \multirow{2}{*}{ Parameter } & \multicolumn{2}{|c|}{ Surface } & \multicolumn{2}{|c|}{ Depth Profiles } \\
\hline & $r$ & $n$ & $r$ & $n$ \\
\hline Nitrate & $-0.81 \cdots$ & 20 & $-0.93 \cdots$ & 23 \\
\hline Ammonium & $-0.87^{\cdots}$ & 23 & $+0.97 \cdots$ & 21 \\
\hline Phosphate & $-0.76 \cdots$ & 22 & $-0.86^{\cdots}$ & 24 \\
\hline Chlorophyll a & $+0.82 \cdots$ & 23 & +0.33 & 17 \\
\hline Bacterial abundance & $-0.52 \cdots$ & 33 & -0.39 & 24 \\
\hline Thymidine incorporation & +0.01 & 23 & +0.08 & 17 \\
\hline Leucine incorporation & +0.38 & 22 & -0.12 & 18 \\
\hline \multicolumn{5}{|l|}{ Microflagellates } \\
\hline Heterotrophs & -0.15 & 23 & -0.38 & 16 \\
\hline Autotrophic & $+0.56 \cdots$ & 23 & $+0.69 \cdot$ & 16 \\
\hline $\begin{array}{l}\text { Ratio of heterotrophic } \\
\text { microflagellates to bacteria }\end{array}$ & $-0.46^{\circ}$ & 23 & +0.14 & 16 \\
\hline$\cdot p<0.05 ; \cdots p<0.001$ & & & & \\
\hline
\end{tabular}

Table 2. Least-squares analyses (Model II) of inorganic nutrient concentrations versus salinity in horizontal transects and depth profiles of the Rhone River plume, January 1987

\begin{tabular}{|c|c|c|c|c|c|c|}
\hline & \multicolumn{3}{|c|}{ Horizontal transects } & \multicolumn{3}{|c|}{ Depth profiles } \\
\hline & Slope & Error & $n$ & Slope & Error & $n$ \\
\hline Nitrate & -1.58 & 0.25 & 22 & -1.90 & 0.16 & 23 \\
\hline Ammonium & -0.25 & 0.03 & 23 & -0.27 & 0.02 & 21 \\
\hline Phosphate & -0.12 & 0.02 & 22 & -0.11 & 0.01 & 24 \\
\hline
\end{tabular}




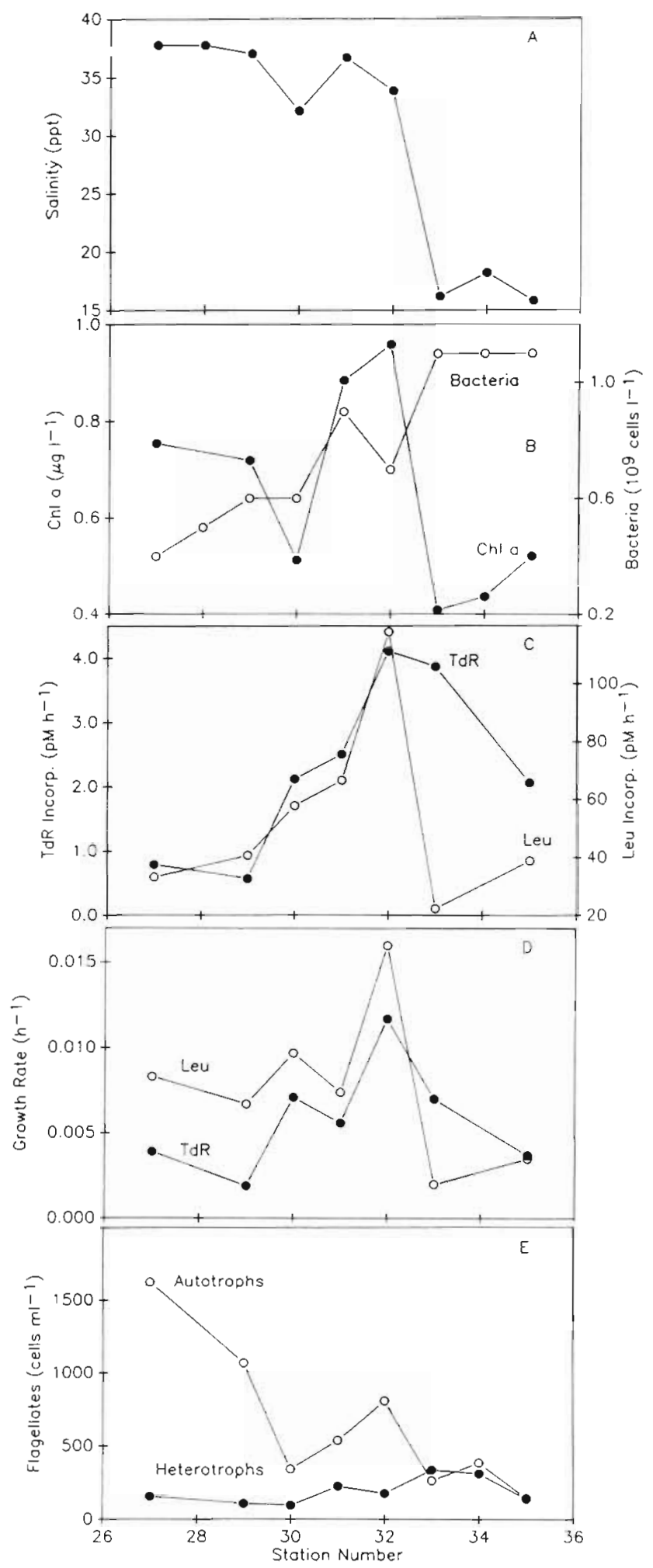

Fig. 3. Transect of salinity and microbial parameters in Rhone River plume on Jan 29, 1987. Stations were $1 \mathrm{~km}$ apart. Stn 36 is near the mouth of the river and Stn 26 is at the west end of the transect. (A) Salinity; (B) chlorophyll (chl a) and bacterial abundance; (C) thymidine (TdR) and leucine (Leu) incorporation rates; (D) bacterial growth rates determined from Leu and

$T d R$ incorporation rates; (E) microflagellate abundance were about 9,50 and $5 \mu M$ for ammonium, nitrate and phosphate, respectively, decreasing to detection limits for all 3 nutrients when salinity reached the Mediterranean value. The negative relationship with salinity was observed in depth profiles and horizontal transects (Table 1). A simple linear regression described most of the variation between salinity and the dissolved nutrients, suggesting that high plume concentrations were diluted conservatively with the low Mediterranean concentrations. No obvious nonlinearity was observed in plots of concentrations vs salinity and correlation coefficients were generally $>0.80$ (Table 1 ).

Horizontal and vertical mixing of nutrients produced the same concentration distributions. The slopes of least-squares fits of concentration vs salinity for horizontal transects were not statistically different (Student's $t$-test) from similar fits for concentrations and salinities measured in depth profiles (Table 2).

\section{Effect of mixing on biological parameters}

\section{Phytoplankton}

Chlorophyll (chl a) concentrations were highest at or near the plume-sea boundary. In horizontal transects, the maximum chl a concentration was at 2 stations $(2 \mathrm{~km})$ before the plume-sea boundary (Fig. 3); this boundary was defined by a drop in salinity from 34 to $16 \%$ and a drop in $\sigma_{t}$ from 26.0 to 12.5 in $1 \mathrm{~km}$ (Fig. 1). Horizontally, chl a concentrations were highest (nearly $1.0 \mu \mathrm{g} \mathrm{l}^{-1}$ ) at the plume-sea boundary (Fig. 3B). In depth profiles, maximum chl a was just above the bottom of the low salinity layer (Fig. 4). That is, chl a was highest just above the plume-sea interface. In horizontal transects, there was a significant, positive correlation $(p<0.05 ; r=$ +0.82 ) between chl $a$ and salinity, whereas the correlation was still positive, but not statistically significant for depth profile samples $(p>0.05 ; r=+0.33$ ) (Table 1$)$.

\section{Bacteria}

Virtually all parameters of the heterotrophic bacterial assemblage were highest at the plume-sea boundary, whether the boundary was horizontal or vertical. Thymidine and leucine incorporation rates, which are indices of bacterial production, were highest at the edge of the plume, close to the peak in chl a (Fig. 3). Likewise, in depth profiles incorporation rates were highest at $100 \mathrm{~cm}$, which again was the location of the chl a peak and the boundary between the low salinity top layer and the high salinity Mediterranean Sea (Fig. 4). Not surprisingly, the correlation between incorporation rates and salinity was low (Table 1 ). 


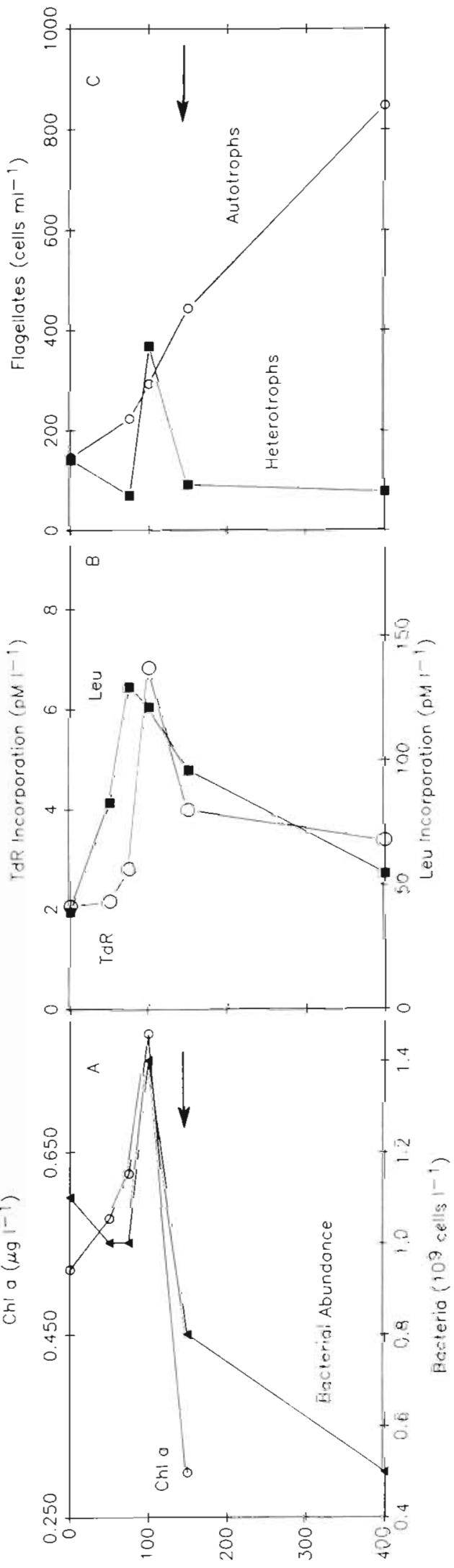

(wo) 4:000
Although peaks in bacterial production coincided with peaks in chl $a$, overall the correlation between production and chla was weak. The correlation between thymidine incorporation and chl a was $r=$ +0.34 , which is barely statistically significant (for $p$ $<0.05, r$ must be $>0.32)$; the correlation between leucine incorporation and chl $a$ was not significant ( $r=$ $+0.31, p>0.05$ ). When horizontal transect and depth profile samples are considered separately, the correlation between thymidine incorporation and chl $a$ is not statistically significant.

Overall, thymidine and leucine incorporation rates gave similar estimates of bacterial production. Thymidine incorporation rates varied from 0.5 to $7 \mathrm{pM} \mathrm{h}^{-1}$ whereas leucine incorporation rates varied from 20 to $130 \mathrm{pM} \mathrm{h}^{-1}$. Based on literature conversion factors, these incorporation rates convert to ranges of 20 to

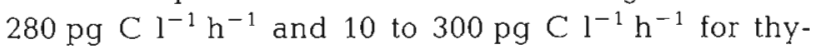
midine and leucine incorporation rates, respectively. The overall correlation between these incorporation rates was high, $r=0.67$ ( $p<0.01$; Fig. 5).

Growth rates (averaged for the entire bacterial assemblage) can be estimated by dividing the production rates by the bacterial abundance. During horizontal transects, growth rates were highest at the plume-sea boundaries (Fig. 3). Average growth rate increased from 0.002 to $0.012 \mathrm{~h}^{-1}$ (Fig. 3D). The distribution of growth rates with depth was more complicated (Fig. 6). In one profile, growth rates were higher in the Mediterranean

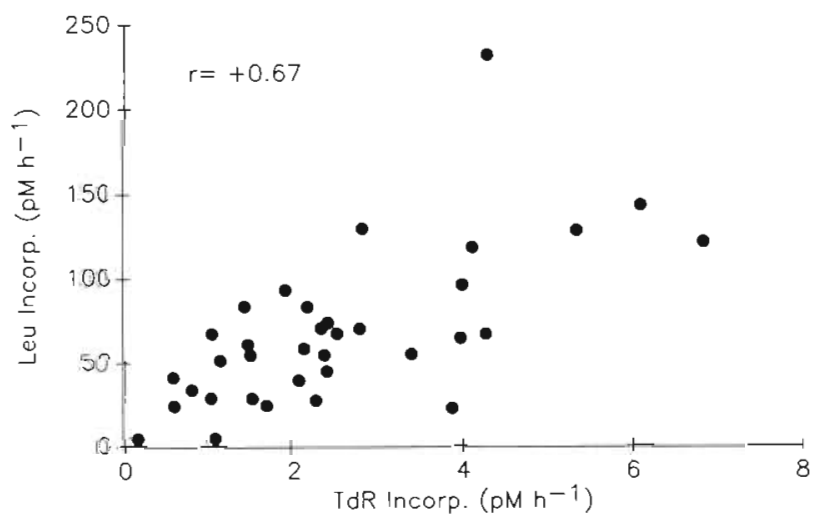

Fig. 5. Comparison of thymidine (TdR) and leucine (Leu) incorporation rates. All data were included

Sea layer (Fig. 6). In 2 other profiles, bacterial growth rates were highest at the plume-sea boundary (Fig. 6).

The frequency of dividing cells (FDC) was also measured, but no obvious patterns with depth or in horizontal transects were observed. The correlation with thymidine or leucine incorporation rates per cell were both low, $r=0.13$ and $r=0.28$, respectively $(p>0.05)$. 
Bacterial abundance was highest at $100 \mathrm{~cm}$, corresponding to the peak in bacterial production (thymidine and leucine incorporation) (Fig. 4). However, there was no obvious peak in abundance at the hori-

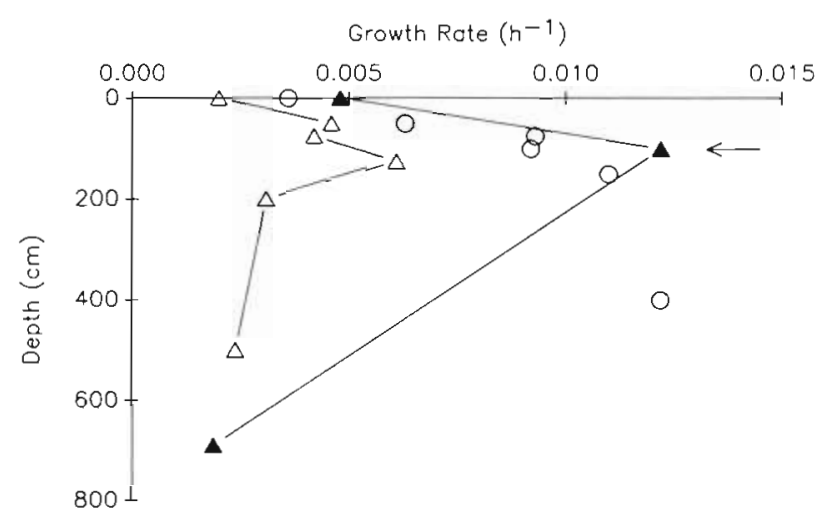

Fig. 6. Depth profile of bacterial growth rates on Jan 27 (4), 28 $(\Delta)$ and $29(0), 1987$ in the Rhone River plume. Values are means of $\mathrm{TdR}$ and Leu-based rates. Arrow indicates plumesea boundary as defined by salinity (see Fig. 2)

zontal plume-sea boundary (Fig. 3). Bacterial abundance simply was higher (1.1 vs $0.4 \times 10^{9}$ cell $\left.1^{-1}\right)$ in the plume (Fig. 3). The correlation between bacterial abundance and salinity was significant for horizontal transects but not for depth profiles (Table 1). The correlation between bacterial abundance and chl a was not significant $(r=-0.12$ and +0.25 for horizontal and vertical transects respectively; $p>0.05)$.

Chlorophyll concentrations were converted to phytoplankton biomass by assuming that chl a: carbon $=50$. Bacterial abundance was converted to bacterial biomass by assuming $20 \mathrm{fg} \mathrm{C}$ cell $^{-1}$ (Lee \& Fuhrman 1987). Often the ratio of bacterial to phytoplankton biomass was very high, sometimes higher than 1 (Fig. 7). There was a significant inverse relationship $(r=-0.72$ and

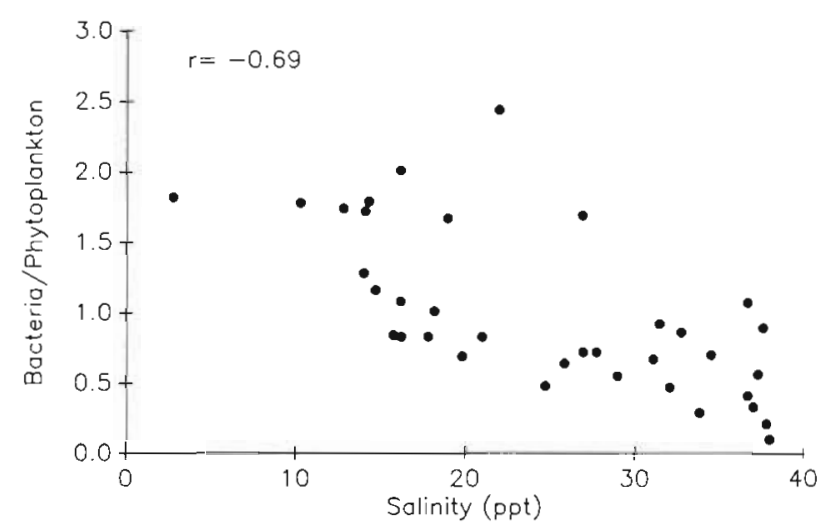

Fig. 7 Ratio of bacterial biomass to phytoplankton biomass versus salinity. All data were included
-0.62 for horizontal and vertical transects, respectively: $p<0.05$ ) between the biomass ratio and salinity (Fig. 7). Relative to phytoplankton biomass, bacterial biomass was highest in low salinity waters characteristic of the Rhône plume.

\section{Microflagellates}

We observed higher numbers of autotrophic microflagellates in the Sea than in other waters in depth profiles (Fig. 4C) and in horizontal transects, although there was a secondary peak at the horizontal plumesea boundary (Fig. 3E). There was a positive correlation between the abundance of the chl a-containing microflagellates and salinity ( $p<0.05$; Table 1 ).

The abundances of autotrophic and heterotrophic microflagellates did not covary. Unlike the autotrophs, there was a negative correlation between the abundance of heterotrophic microflagellates and salinity, although this was not statistically significant (Table 1). In the depth profile and horizontal transect discussed in detail here, heterotrophic microflagellates were most abundant at plume-sea interfaces (Figs. 3E and $4 \mathrm{C}$ ). However, when all the data were considered together based on salinity, the abundance of heterotrophic microflagellates clearly decreased along the plumeboundary waters-sea gradient (Table 3 ).

We divided all data into 3 categories based on salinity: plume, boundary waters, and Mediterranean Sea (Table 3). Chlorophyll and abundance of autotrophic microflagellates increased along the plume-boundary waters-sea gradient (Table 3 ). Also, bacterial production was enhanced nearly 2 -fold in boundary waters (Table 3).

In contrast, the abundance of heterotrophic microflagellates decreased by about $50 \%$ along the plumeboundary waters-sea gradient (Table 3). Bacterial abundance also decreased, but much less so than heterotrophic microflagellates (Table 3). As a consequence, there was a negative correlation between salinity and the ratio of bacterial abundance to heterotrophic microflagellate abundance. This correlation was significantly negative $(r=-0.46 ; p<0.05)$ for horizontal transects, although not for depth profiles $(r=+0.14 ; p>0.05)$ (Table 1$)$.

\section{DISCUSSION}

We observed that bacterial production, as estimated by both thymidine and leucine incorporation, were enhanced at boundaries between the Rhône River plume and the Mediterranean Sea. One explanation is that the enhanced bacterial activity is simply a result of 
Table 3. Summary of selected microbial parameters ( \pm SE) for the Rhone River plume, boundaries between the plume and the Mediterranean Sea, and the Mediterranean Sea. The plume was defined by water with salinity $<20 \%$. Average salinity for this group was $16.0 \pm 0.6$. Minimum number of samples in this group was 14 . Boundaries were defined by water with salinity between 20 and $35 \%$. Average salinity for this group was $26.7 \pm 1.5$. Minimum number of samples in this group was 19. Mediterranean Sea was defined by water with salinity $>35 \%$. Average salinity for this group was $36.7 \pm 0.3$. Minimum number of samples in this group was 8

\begin{tabular}{|c|c|c|c|}
\hline Parameter & Plume & Boundaries & Sea \\
\hline $\operatorname{Chl} a\left(\mu \mathrm{g}^{-1}\right)$ & $0.41(0.03)$ & $0.61(0.05)$ & $0.63(0.07)$ \\
\hline Autotrophic flagellates (cells $\mathrm{ml}^{-1}$ ) & $292(47)$ & $758(143)$ & $978(161)$ \\
\hline Bacterial production ${ }^{\natural}\left(\mathrm{pgC} \mathrm{I}^{-1} \mathrm{~h}^{-1}\right)$ & $88(11)$ & $152(21)$ & $87(22)$ \\
\hline Abundance $\left(10^{6}\right.$ cells $\left.\mathrm{ml}^{-1}\right)$ & $1.2(0.1)$ & $1.2(0.1)$ & $0.8(0.1)$ \\
\hline Heterotrophic flagellates (cells $\mathrm{ml}^{-1}$ ) & $305(57)$ & $231(32)$ & $137(25)$ \\
\hline
\end{tabular}

higher rates of phytoplankton production. We did observe that peaks of bacterial abundance and production correlated with peaks in chlorophyll concentrations. Over large time and space scales there is a good correlation between bacterial biomass and production and phytoplankton biomass and production (Bird \& Kalff 1984, Cole et al. 1988). If this bacteriaphytoplankton correlation applies to the Rhone River plume, then explaining the high bacterial production at plume-sea interfaces depends on understanding why phytoplankton production is high at these interfaces (assuming that high chl a implies high primary production; study in May 1988 did find that high primary production rates coincided with high chl a concentrations)

Our study was not designed to examine controls of phytoplankton production, but one hypothesis can be suggested. Perhaps phytoplankton production is relatively low in the Rhône River because of turbidityinduced light limitation; production in the Mediterranean Sea is clearly nutrient limited. At plume-sea boundaries, mixing reduces turbidity while nutrients remain high enough to support enhanced primary production. Further away from our study area in the mouth of the Rhône, chl a decreases (Mimura et al. 1988).

Regardless of what is limiting the phytoplankton, the hypothesis that enhanced bacterial activity was due solely to enhanced phytoplankton production is not consistent with all the data. Maximum bacterial production coincided with peaks in chl a in depth profiles, but these maxima were offset in horizontal transects (Figs. 3 and 4). The overall correlation between bacterial abundance and chl a was not significant, and the correlation between bacterial production and chl $a$ was weak at best; only when all data were lumped together was the correlation between thymidine incorporation and chl a significant. The correlation between leucine incorporation and chl a was insignificant. Also, bacterial biomass was elevated in low salinity waters rela- tive to phytoplankton biomass (Fig. 7) and microflagellate numbers (Table 3).

Bacterial production supported by the allochthonous carbon probably explains why the ratio of bacterial to phytoplankton biomass was greater than one for low salinity values and why there was a poor correlation between bacterial and phytoplankton parameters. However, it does not explain why the ratio of bacterial numbers to microflagellate numbers varied inversely with salinity, nor is it clear why bacterial growth rates are maximal at the horizontal plume-sea boundary where presumably organic-rich river water has been diluted by nutrient-poor Mediterranean water. The expected pattern would have been a monotonic decrease in bacterial growth rates as salinity increased due to mixing.

In his study of the Fraser River plume, Albright (1983) found that bacterial production but not primary production was highest at salinities in between river and oceanic values. Albright (1983) suggested that the concentration of oxidized nutrients (nitrate and phosphate) increased as the Fraser River plume mixed with oceanic waters, which in turn stimulated bacterial production. He did find that addition of these nutrients increased bacterial production (Albright 1983). However, inorganic nutrients are not limiting production in the Rhône River plume because nitrate and phosphate concentrations are high.

We suspect that the enhanced bacterial production at plume-sea boundaries is analogous to experiments in which whole water is added to filter-sterilized water (e.g. Fuhrman \& Azam 1980, Kirchman et al. 1982, 1984). In these experiments, bacterial abundance increases exponentially (sometimes after a lag), at least in part because of decreased grazing pressure (Landry \& Hassett 1982, Tremaine \& Mills 1987). Even more noteworthy is that rates of both thymidine and leucine incorporation often increase much more so than bacterial abundance (e.g. Ducklow \& Hill 1985, Kirchman \& Hoch 1988). Similarly, we suppose that the Mediterranean Sea, which has low 
microflagellate abundance relative to plume waters (Table 3), dilutes grazer abundance and grazing pressure on bacteria as DOM-rich plume waters mix with the sea. The end result is the observed increase in bacterial production at plume-sea boundaries.

In support of the dilution hypothesis, we observed that heterotrophic microflagellates in the plume were apparently diluted by the Mediterranean Sea during mixing. This observation became obvious after we divided all data into 3 categories based on salinity (Table 3). Although lumping the data obscures differences between horizontal transects and depth profiles, it increases our sample size and greatly simplifies comparisons. The most important observation to emerge from Table 3 is that the abundance of heterotrophic microflagellates decreased by $50 \%$ along the plumeboundary waters-sea gradient. Bacterial abundance also decreased, but much less so than heterotrophic microflagellates (Table 3 ).

The $50 \%$ decrease in the abundance of heterotrophic microflagellates is roughly that expected from conservative mixing of the plume and sea values; average salinity increases from 16 to $37 \%$ or roughly $50 \%$ as the plume (as defined in Table 3) and sea mix. In contrast, bacterial abundance dropped $33 \%$ on average (Table 3), indicating that there was a net production of cells along this gradient. This net production of cells is only possible if grazing was unable to match increased bacterial production. In short, mixing apparently caused primary production to increase and diluted grazing pressure by microflagellates, both of which contributed to a 2 -fold enhancement of bacterial production in plume-sea boundary waters.

The key to our dilution hypothesis is that mixing must be rapid compared to the response of grazers to increases in their bacterial prey, but slow enough to allow bacteria to 'shift up' their growth rate. First, we need to obtain a rough estimate of the mixing time scale and then we can consider how fast bacteria and grazers respond.

The lifetime of the plume was probably less than a week and the time scale of mixing is likely to be on the order of a day. Three days before our study began, winds from the north ('mistral') were very strong (150 $\mathrm{km} \mathrm{h}^{-1}$ ), which undoubtedly caused strong vertical mixing It is highly unlikely that a low salinity plume would have been observed at our stations during high winds. Thus, the thin layer of low salinity-high nutrient waters and the associated enhanced bacterial production at plume-sea boundaries were $<3 \mathrm{~d}$ old. The patchy density distribution observed during 2 horizontal transects (Fig. 1) and variability with depth further emphasize the transient nature of the plume. During its lifetime, the plume is roughly only $100 \mathrm{~cm}$ thick; salinity, inorganic nutrients (this study), and DOM concen- trations (G. Cauwet unpubl.) differ by 3 -fold from the sea. When strong mixing re-occurs, these steep gradients imply that the bacterial environment is likely to change greatly within a day or less.

Thus the time scale of plume-sea mixing appears to be on the order of a day, if not less. When bacteria are diluted by filtered water, abundance and production can increase within a day (Fuhrman \& Azam 1980, Kirchman et al. 1982, Kirchman et al. 1984). A more thorough analysis of 'shift up' experiments found that the response time of bacteria is on the order of a few hours, even when generation times are greater than a day (Chin-Leo \& Kirchman unpubl.).

In contrast, bacterivores apparently do not keep up with the bacteria, and grazing pressure does not match increases in bacterial production, which is evident from the net increase in bacterial abundance following dilution (Fuhrman \& Azam 1980, Kirchman et al. 1982 Kirchman et al. 1984). In seawater culture experiments microflagellates abundance is highest several days after the peak in bacterial abundance (Van Wambeke \& Bianchi 1985). It is not quite clear why bacterial grazers do not respond immediately to increases in their prey, since doubling times of bacterivores are probably nearly as fast, if not equal to the doubling times of bacteria (e.g. Sherr et al. 1983). In short, both the functional and numerical response of bacterivores lags behind, by at least a day if not more, increases in bacterial numbers and production.

The steady-state or 'average' relationship among phytoplankton, bacteria and their grazers seems fairly clear now, but still we do not know. (1) the frequency and qualitative importance of non-steady-state conditions, such as unbalanced growth (Kirchman et al. 1986), and (2) the factors leading to non-steady-state conditions and disruption of normal microbial loop relationships. Our study has suggested 2 likely factors. The first factor is the input of allochthonous DOM which allows for bacterial growth independent of phytoplankton production. This factor is not unique to river plumes and has been suggested for salt marshes (Wright \& Coffin 1983) and estuaries (Kirchman \& Hoch 1988). The second factor is the speed at which growth conditions change. Not unexpectedly, our results suggest that bacteria can respond rapidly to favorable growth conditions and, in the case of the Rhône River plume, shift up growth rates from 0.002 to $0.014 \mathrm{~h}^{-1}$ apparently within a day. The apparent inability of bacterivores to 'keep up' may result in unusual microbial loop relationships. This imbalance between bacteria and their grazers of course cannot last indefinitely and may be characteristic of systems undergoing rapid changes in abiotic factors. Transient events that affect bacterial growth conditions are likely to occur even in the open ocean, if episodic blooms of phytoplankton 
turn out to be common as recently suggested by Jenkins \& Goldman (1985) and Lohrenz et al. (1988). In short, to understand what controls microbial loop dynamics, it seems important to examine the response time of bacteria to changes in growth conditions (particularly DOM) and probable bacterial 'blooms' that occur because of the lag between increases in bacterial production and the response of bacterivores.

Acknowledgements. This work was supported by C.N.R.S. and by a grant from the National Science Foundation (OCF 8614170). Travel expenses for D.K. were provided by the Ministère des Relations Exterieures (Ambassade de France, Washington, D.C.). We also thank A. Bianchi for his support and hospitality during this research.

\section{LITERATURE CITED}

Albright, L. J. (1983). Heterotrophic bacterial biomasses, activities, and productivities within the Fraser River Plume. Can. J. Fish. aquat. Sci. 40 (Suppl. 1): 216-220

Aloisi, J.-C., Millot, C., Monaco, A., Paue. (1979). Dynamique des suspensions et mecanismes sedimentogenetiques sur le plateau continental du Golf du Lion. C. r. hebd. Séanc. Acad. Sci. Paris 289: 879-882

Bird, D. F., Kalff, J. (1984). Empirical relationships between bacterial abundance and chlorophyll concentration in fresh and marine waters. Can. J. Fish. Aquat. Sci. 41: 1015-1023

Blanc, F., Leveau, M., Szekielda, K. H. (1969). Effets eutrophiques au debouche dun grand fleuve (Grand Rhône). Mar. Biol. 3: 233-242

Cole, J. J., Findlay, S. Pace, M. L. (1988). Bacterial production in fresh and saltwater ecosystems: a cross-system overview. Mar. Ecol. Prog. Ser. 43: 1-10

Ducklow, H. W. (1983). The production and fate of bacteria in the ocean. BioScience 33: 494-501

DuckJow, H. W., Hill, S. M. (1985). Tritiated thymidine incorporation and the growth of heterotrophic bacteria in warm core rings. Limnol. Oceanogr. 30: 260-272

Ducklow, H. W., Kirchman, D. L. (1983). Bacterial dynamics and distribution during a spring diatom bloom in the Hudson River plume, USA. J. Plankton Res. 5: 333-355

Fuhrman, J. A., Azam, F. (1980). Bacterioplankton secondary production estimates for coastal waters of British Columbia, Antarctica, and California. Appl. environ. Microbiol. 39: 1085-1095

Fuhrman, J. A., Azam, F. (1982). Thymidine incorporation as a measure of heterotrophic bacterioplankton production in the Southern California Bight. Mar. Biol. 66: 109-120

Hobbie, J. E., Cole, J. J. (1984). Response of a detrital foodweb to eutrophication. Bull. mar. Sci. 35: 357-363

Jenkins, W. J., Goldman, J. C. (1985). Seasonal oxygen cycling and primary production in the Sargasso Sea. J. mar Res. 43: 465-491

Kirchman, D., Ducklow, H. W., Mitchell, R. (1982). Estimates of bacterial production and growth rates based on changes in biomass and uptake rates. Appl. environ. Microbiol. 44: 1296-1307

Kirchman, D. L., Hoch, M. P. (1988). Bacterial production in

This article was presented by Dr S. Y. Newell, Sapelo Island, Georgia, USA the Delaware Bay estuary estimated from thymidine and leucine incorporation rates. Mar. Ecol. Prog. Ser. 45: 169-178

Kirchman, D., Knees, E. Hodson, R. (1985). Leucine incorporation and its potential as a measure of protein synthesis by bacteria in natural aquatic systems. Appl. environ. Microbiol. 49: 599-607

Kirchman, D. L., Murray, R. E., Hodson, R. E. (1986). Rates of DNA and protein synthesis by heterotrophic bacteria in aquatic environments: a comparison between the thymidine and leucine approaches. In: Megyśar, F., Gantar, M. (eds.) Proc. Fourth International Symposium of Microbial Ecology, Sbvene Society for Microbiology, Ljubljana, Yugoslavia, p. 631-637

Kirchman, D., Peterson, B., Juers, D. (1984). Bacterial growth and tidal variation in bacterial abundance in the Great Sippewissett Salt Marsh. Mar. Ecol. Prog. Ser. 19: 247-259

Landry, M. R., Hassett, R. P. (1982). Estimating the grazing impact of marine micro-zooplankton. Mar. Biol. 67: 283-288

Lee, S., Fuhrman, J. A. (1987). Relationships between biovolume and biomass of naturally derived marine bacterioplankton. Appl. environ. Microbiol. 53: 1298-1303

Lohrenz, S. E., Arnone, R. A., Wiesenburg, D. A., DePalma, I. P. (1988). Satellite detection of transient enhanced primary production in the western Mediterranean Sea. Nature, Lond. 335: 245-247

Mimura, T., Romano, J.-C., de Souza-Lima, Y. (1988). Microbiomass structure and respiratory activity of microneuston and microplankton in the northwestern Mediterranean Sea influenced by Rhône river water. Mar Ecol. Prog. Ser. 49: $151-162$

Neveux J. (1976). Dosage de la chlorophylle a et de la pheophytine a par fluorimetrie. Annls Inst. océanogr. 52: 165-174

Porter, K. G., Fieg, Y S. (1980). The use of DAPI for identifying and counting aquatic microflora. Limnol. Oceanogr. 29: 943-948

Sherr, E. B., Sherr, B. F. (1983). Double-staining epifluorescence technique to assess frequency of dividing cells and bacterivory in natural populations of heterotrophic microprotozoa. Appl. environ. Microbiol. 46: 1388-1393

Sherr, B. F., Sherr, E. B., Berman, T (1983). Grazing, growth and ammonium excretion rates of a heterotrophic microflagellate fed with four species of bacteria. Appl. environ. Microbiol. 45: 1196-1201

Strickland, J. D., Parsons, T R. (1972). A practical handbook of seawater analysis. Fish. Res. Bd Can. Bull 167: 1-311

Tremaine, S. C., Mills, A. L. (1987). Tests of the critical assumptions of the dilution method for estimating bacterivory by microeucaryotes. Appl. environ. Microbiol. 53: 2914-2921

Van Wambeke, F. (1988). Numeration et taille des bacteries planctoniques au moyen de l'analyse d'images. Annls Inst. Pasteur Microbiologie 139: 261-272

Van Wambeke, F., Bianchi, M. A. (1985). Bacterial biomass production and ammonium regeneration in Mediterranean seawater supplemented with amino acids. 2. Nitrogen flux through heterotrophic microplankton food chain. Mar. Ecol. Prog. Ser. 23: 117-128

Wright, R. T., Coffin, R. B. (1983). Planktonic bacteria in estuaries and coastal waters of N. Massachusetts: spatial and temporal distribution. Mar. Ecol. Prog. Ser. 11: 205-216

Manuscript first received: November 1, 1988 Revised version accepted: February 9, 1989 